\title{
INFLATION TARGETING AS A MONETARY POLICY STRATEGY (APPLICABLE IN NON- EU TRANSITION ECONOMIES)
}

\author{
Stojnic Milica ${ }^{1}$
}

\begin{abstract}
Since the 1990s a large number of industrial countries and a growing number of emerging market and transition economies have adopted inflation targeting. During the process of implementation, emerging markets and especially transition economies face many challenges. Nevertheless, the list of inflation targeting countries is really never final. On the other hand, there are not too many transition economies that have adopted this monetary policy strategy. Such examples in the SEE region are Serbia and Albania. However, there is no fixed pattern and thus countries must learn along the way from one another, and more importantly, from their own experience.
\end{abstract}

This paper provides an overview on inflation targeting as a monetary policy strategy, the necessary preconditions for its successful implementation, its advantages and disadvantages, issues and challenges that emerging markets and transition economies face, while defining, and during the implementation of this monetary policy strategy.

Key words: inflation targeting / monetary policy / price stability / Central Bank / financial stability

\section{INFLATION TARGETING AS A MONETARY POLICY STRATEGY}

Macroeconomic policy of any country has several goals that are based on increase in employment, economic stability, economic development and production growth. Those goals are achieved by appropriate fiscal and monetary policy led by "most important players in financial markets" (Mishkin, 2009, p. 315), Central Banks. Healthy macroeconomic policy means healthy economy which can be achieved through one of three monetary strategies: monetary targeting, inflation targeting

1 University of Business Academy in Novi Sad, The Faculty of Economics and Engineering Management in Novi Sad, Cvecarska 2, e-mail: milicastojnic85@gmail.com 
and implicit nominal anchor (Mishkin, 2009, p. 395). Central banks are held highly accountable for the conduct of monetary policy and hitting the targets. In other words, those regimes appear to be highly transparent. Furthermore, what is common for these three strategies is that all three focus on price stability, which is, for most Central Banks of the world, the main monetary policy goal. Not so long ago policy makers reintroduced the idea of targeting. Monetary targeting was introduced for the first time during the 1970s and 1980s, followed by introduction of inflation targeting in 1989 in New Zealand (Cukierman, 1996, p. 27).

As defined by Mishkin (2009, p.395), monetary targeting delineates that "the central bank announces that it will achieve a certain value (the target) of the annual growth rate of a monetary aggregate", but not at a constant rate. According to Amato and Gerlach (2001), different studies suggest five criteria that describe and closely determine the spirit of inflation targeting: "1. Public announcement of a numerical target for inflation, 2. a commitment to price stability as the overriding goal of policy, 3. the use of an information-inclusive strategy, 4. Adoption of high levels of transparency, 5. Accountability." (Amato and Gerlach, 2001, p. 781).

Even though inflation targeting was introduced in developed market economies, this monetary policy framework has been adopted by a growing number of emerging market and transition economies. In 2009, IMF classified twenty six countries as inflation targeting (Scott, 2009, p. 3). However, numerous empirical studies and, more importantly, experience has showed that the success of inflation targeting and its adoption varies across emerging markets and transition economies since it depends on diverse factors such as economic structure and level of income for example. In other words, the exchange rate and financial crises in the 1990s made inflation targeting an "increasingly attractive alternative" (Mishkin, 2000, p. 1) for many emerging markets and transition economies.

Figure 1: Evolution of Monetary Policy Regimes, 1989-2008 (Scott, 2009, p. 5)

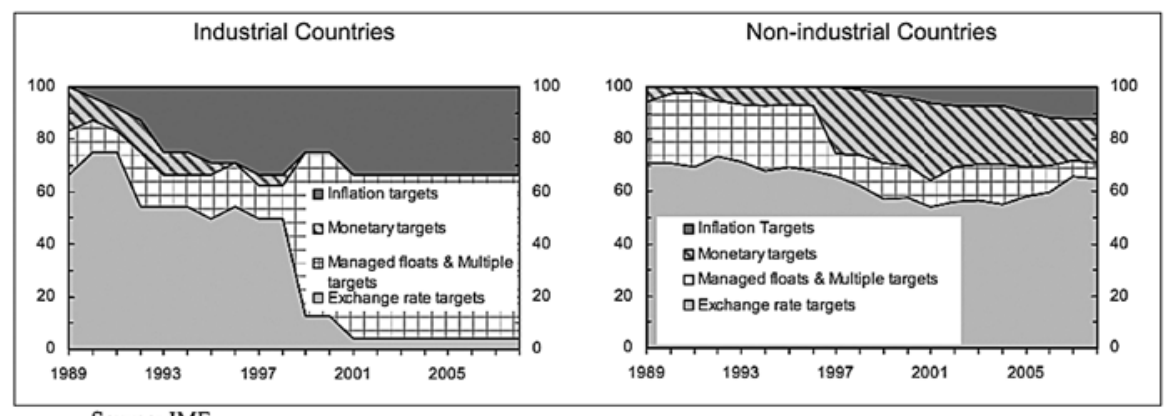

Source: IMF. 
Nevertheless, certain common features of emerging markets and transition economies, "given the underdevelopment of their financial systems" (Mukherjee and Battacharya, 2011, p. 6) affect the effectiveness of monetary policy. Those features are mainly institutional, which besides the lack and underdevelopment of financial systems "dominated by banks" (Mukherjee and Battacharya, 2011, p. 6) are also affected by the underdevelopment and instability in EMEs judicial systems, interbank markets, etc. (Mukherjee and Battacharya, 2011).

\section{PRECONDITIONS FOR INFLATION TARGETING}

According to literature, in order to adopt inflation targeting, central bank needs to satisfy certain preconditions. Adoption of inflation targeting relies on: 1. Central bank independence, 2. Healthy and sound fiscal policy, 3. Elasticity of economy towards changes in interest and exchange rates (Amato and Gerlach, 2001, p. 782). Jeffery D. Amato (2001) in his paper stated that those preconditions are necessary for adoption and success of any monetary policy strategy, not just inflation targeting. However, experience in practice has shown that preconditions play an unusually small part before adopting inflation targeting and quite a larger one after the adoption of this monetary policy strategy.

These so-called preconditions are particularly important for emerging markets and transition economies, as they affect inflation expectation, effectiveness of monetary policy and stability of financial sector. Movements in governmental spending tend to create large movements in inflation expectation and inflation itself (Amato and Gerlach, 2001). Furthermore, high exchange rates may result from adoption of inflation targeting which in emerging market economies, because of the lack of domestic capital, force borrowings in foreign currency. Besides, by targeting inflation central bank usually directs restrictive policy. More specifically, central bank raises interest rates as a response to depreciation of a national currency (Amato and Gerlach, 2001). For these reasons, it can be implied that "the central bank cannot pursue and achieve multiple goals with only one basic instrument" (Scott, 2009, p. 7).

Worth mentioning is a phase of disinflation, that most of the countries that have adopted inflation targeting, went through (Scott, 2009). Firstly, the inflation was reduced by "setting year by year targets" (Scott, 2009, p. 5), and then the process was followed by the adoption of stable inflation targets (Scott, 2009). This will be discussed more thoroughly further on. 


\section{ADVANTAGES OF INFLATION TARGETING}

Monetary policy performance has been quite successful in inflation targeting economies. Inflation rates and inflation expectations are significantly reduced (Mishkin, 2009). For these reasons, it can be said that inflation targeting, as a monetary policy strategy, has several advantages.

First of all, unlike monetary targeting, inflation targeting uses all available information in order to achieve optimal monetary policy outcome (Mishkin, 2000).

Secondly, it is highly transparent and very easy to understand. In other words, it is highly accessible to the public. For example, inflation targeting central banks publish Inflation Report in which they state explicit numerical inflation target. For this reason, central banks are held highly accountable for their actions and there is less probability that they "will fall into time-inconsistency trap" (Mishkin, 2000, p. 2 ), because they focus on meeting the targets.

Furthermore, central banks in inflation targeting countries have consistent communication with the government as well. This is why central bank independence, implying instrument and goal independence, is important since the time-inconsistency problem usually takes a form of political pressures on central bank to lead a rather "overly expansionary monetary policy" (Mishkin, 2000, p. 2). This is particularly important in emerging market and transition economies due to their volatile history of poor monetary policy management (Mishkin, 2000).

Probably the most salient feature of inflation targeting central banks, as already mentioned, is transparency. By being transparent, central banks, at the same time, are accountable for the conduct of monetary policy. Moreover, accountability helps in building public support for central bank independence.

\section{DISADVANTAGES OF INFLATION TARGETING}

According to Frederic S. Mishkin (2009) there are four main criticisms of inflation targeting. The first criticism refers to the later signals of inflation targeting to public and policy makers due to the fact that inflation is not easily controllable. In more precise terms, "because of the long lags in the effects of monetary policy, inflation outcomes are revealed only after a substantial lag" (Mishkin, 2009, p. 403). As a consequence, central bank's accountability is going to be seriously affected. 
Secondly, inflation targeting is usually seen as rigid rule that distracts and limits policy makers to respond to sudden changes (Mishkin, 2009). However, in practice, inflation targeting is very flexible. In fact, it uses all available information in order to achieve the pre-announced inflation targets. Therefore, it can be concluded that this is not so serious criticism if inflation targeting strategy is well defined (Mishkin, 2000).

Another criticism of inflation targeting refers to output fluctuations as a consequence of "a sole focus on inflation" (Mishkin, 2009, p. 404). In other words, critics fear that inflation targeting will increase output volatility and hence jeopardize growth (Mishkin, 2000). There is also a concern that central banks might ignore other stabilization goals such as output and employment which will most probably affect growth (Mishkin, 2009).

\section{ISSUES AND CHALLENGES OF INFLATION TARGETING IN EMERGING MARKET AND TRANSITION ECONOMIES}

As previously stated, before adopting steady inflation targets many countries went through disinflation process. Many studies have failed in proving the superiority of inflation targeting over other monetary policy frameworks and importance of inflation targeting role in monetary policy over the time. Consequently, this led to the questioning of disinflationary process and importance of inflation targeting (Cabral, 2006).

Different authors argue about the possibility that samples in the studies questioning the impact of inflation targeting on disinflation might be biased. This is due to the fact that non-targeting economies, as control countries, also put a stress on transparency and accountability as prominent features of monetary policy framework, as targeting countries do. However, these studies include only the developed countries.

In his empirical assessment, Rene Cabral examined a sample of emerging market economies employing both groups, non-targeting economies as a control group and inflation targeting countries. He used the same model that Ball and Sheridan used to assess inflation targeting in developed economies. The sample includes twenty three emerging market economies and eleven of those are inflation targeting economies (Cabral, 2006). The author's results contrast results from Ball and Sheridan's paper. Both cross-sectional and panel analyses proved that inflation targeting mattered for disinflation in emerging market economies. However, this 
paper was written in 2006 before financial crisis and macroeconomic instability could cause different results because emerging market economies are usually the ones that are highly affected (Cabral, 2006). For these reasons, it is particularly interesting to see whether countries that have adopted inflation targeting had a smaller impact on growth after the financial crisis in 2008, compared to noninflation targeting countries. Indeed, IMF paper argues that inflation targeting countries were better at coping with financial shocks from 2007 to 2009 than noninflation targeting countries (IMF, 2009, Abstract). After the financial crisis, in 2009 and 2010 the average growth rate was expected to be lower. Non inflation targeting countries had bigger declines in growth, where in lower-income countries that decline was estimated to be $5 \%$ whereas in inflation targeting it was 3,8\%. In higher-income countries, non inflation targeters had forecasted $4.3 \%$ of decline in growth and inflation targeting countries 3.1\% (Scott, 2009, p. 23).

Figure 2: Growth and Inflation: 2009-2010 forecasts VS. 2001-2008 performance (Scott, 2009, p. 23)

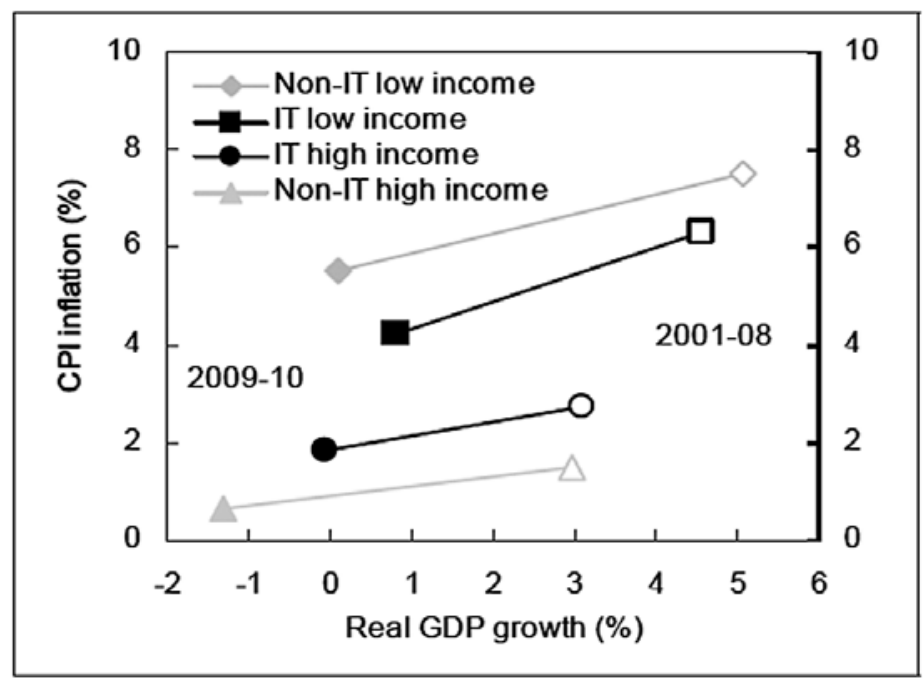

Source: Author's calculations.

However, the main challenge for emerging market and developing economies that have not adopted inflation targeting is to adapt and harmonize inflation targeting framework with the conditions in the country which greatly differ from those in the developed economies (Scott, 2009).

Furthermore, IMF states that emerging market and transition economies, beside various conditions, face many challenges like: "1. Weak public sector financial 
management, 2. Weak financial sector institutions and markets, 3. Low monetary policy credibility, 4. Extensive dollarization of financial liabilities, 5. Vulnerability to sharp changes in capital flows and international investor sentiment" (Scott, 2009, p. 24).

The main challenge in emerging market economies and especially in transition economies is fiscal predominance. Inordinate governmental spending might jeopardize the entire financial stability. Weak fiscal situation in a country might lead to slowing down "the fall in inflation expectation and keeping real interest rates high" (Freedman and Otker-Robe, 2009, p. 13). Furthermore, if fiscal policy is inconsistent with monetary policy, and especially with inflation targeting framework, it might contribute to the damaging credibility of inflation targeting and thus "leading to the collapse of an exchange rate peg" (Scott, 2009, p. 24) and also losing the credibility of central bank. In other words, it should be avoided that future effectiveness of monetary policy be destabilized and jeopardized (Freedman and Otker-Robe, 2009). As stated above, absence of fiscal dominance is a fundamental precondition in "making inflation targeting framework more feasible and less challenging” (Freedman and Otker-Robe, 2009, p. 19).

As discussed in the IMF paper when adopting and implementing inflation targeting, especially in transition economies, environment needs to be taken into account (Scott, 2009). In more precise terms, this refers to the credibility of institutional and market environment. In fact, this is very important from the aspect of financial development, as well. Transition economies generally have very weak institutions and markets which slow down and affect effectiveness of "monetary policy transmission" (Scott, 2009, p. 24). In other words, some countries experiences showed that if basic principles of monetary transmission mechanism are understood- inflation targeting framework is less challenging and more workable (Freedman and Otker-Robe, 2009). Weakness in the financial system (financial institutions and financial markets) affects the performance of inflation targeting as a monetary policy framework, so certain measures and reforms need to be taken in order to make those financial systems stronger and more credible, and thus contribute to financial development (Scott, 2009).

Also, in the creation of an enabling environment for adopting the inflation targeting framework," a more flexible exchange rate regime" (Freedman and OtkerRobe, 2009, p. 20) is necessary to be established. In transition economies the role of exchange rate became even more valuable due to dollarized, or more recently, euroized countries like Central and Eastern European economies. Furthermore, access to international financial markets also plays a significant role for transition 
economies (Scott, 2009). As previously stated weak institutions and markets lead to ineffectiveness of monetary policy transmission, but dollarization and euroization also lead to its modification by emphasizing "exchange rate movements compared to interest rate movements in monetary policy transmission" (Scott, 2009, p. 25).

Furthermore, political support is one of the core elements for successful adoption and implementation targeting as a monetary policy framework. For many transition economies it is going to be a challenge to achieve agreement between the central bank and government during the disinflation process, as was the case in the Czech Republic, Turkey and Poland (Freedman and Otker-Robe, 2009, p. 13). "Maintaining internal consensus and getting broad support" (Freedman and Otker-Robe, 2009, p. 13) are extremely difficult and tremendously challenging.

Institutional independence, which means the central bank's independence, is crucial for the successful adoption and implementation of a stable inflation targeting framework. Different studies on central bank's independence have showed that there is a negative correlation between central bank's independence and inflation. In other words, high independence of central bank lowers the level and variance of inflation (Krause and Mendez, 2008). When we talk about central bank's independence, that primarily refers to goal independence and then instrument independence. Moreover, Krause and Mendez in their empirical study found that a "high level of preference for inflation stability is significantly correlated with CBI measures, membership to the European Economic and Monetary Union" (Krause and Mendez, 2008, p. 285). This is applicable to CEE and SEE countries, particularly in terms of clarity and implementation of inflation targeting as a monetary policy strategy in those countries.

\section{CONCLUSION}

Roger (2009, p. 20) compared similar countries over the same period of time, and concluded that countries which adopted inflation targeting were superior in reducing inflationary impacts, compared to other non-inflation targeting countries. In my opinion, it is still too early to say whether inflation targeters are coping better with inflationary impact, especially after the global financial crisis, because the newly created environment is more unstable and unpredictable and requires even more forward looking central banks (Freedman and Otker-Robe, 2009). Moreover, the key step in the successful adopting of any monetary policy strategy, including inflation targeting, is to adjust the created framework to the conditions and circumstances of a particular country. In other words, transition economies need to understand that the so-far experience has showed that "there is no single 
and most effective path toward the adoption of inflation targeting" (Freedman and Otker-Robe, 2009, p. 19).

For example, Serbia is facing numerous obstacles and challenges during the implementation of inflation targeting regime. One of the challenges is certainly an increase in credibility and efficiency of monetary policy instruments through the development of "currency and capital market" (Fabris, 2006, p. 403). More specifically, more efficient monetary policy instruments will have a better effect on the wide-spread euroisation. However, one of the principal obstacles is insufficient independence of the National Bank of Serbia and monetary policy transparency. Furthermore, monetary policy has experienced not only many positive changes, but also illnesses that the transition process brings along (Momirovic, 2008, p. 72). In my opinion, inflation targeting in Serbia is a reasonable policy despite many challenges. Currently it cannot be concluded "whether the action of NBS was good or premature" (Fabris, 2006, p. 403), but it can be concluded that the entire action was in compliance with "theory literature based on the best practice" (Fabris, 2006, p. 403). However, in my opinion the success of the transition process does not depend on inflation targeting strategy or the selection of a monetary policy strategy. Success is solely based on the quality of institutions in transition countries, as was the case with Poland and Estonia. Countries that became members of the EU showed that inflation targeting strategy gives results, but stable and independent institutions are the ones that create a stable and healthy economic system.

All in all, there is no strictly defined pattern. In adoption and implementation of inflation targeting, transition period might be uncommonly long or quick depending on the starting conditions, but also on "the speed of progress in putting in place the remaining elements" (Freedman and Otker-Robe, 2009, p. 7).

\title{
INFLATORNO TARGETIRANJE KAO STRATEGIJA MONETARNE POLITIKE (PRIMENLJIVOST U NE-EU TRANZICIONIM EKONOMIJAMA)
}

\author{
Stojnić Milica
}

Sažetak: Još tokom 90-ih godina prošlog veka, veliki broj industrijskih zemalja, kao i rastući broj tržišnih ekonomija u nastajanju i tranzicionih ekonomija, usvojile su inflatorno targetiranje. Tokom implementacije, tržišne ekonomije u nastajanju $i$ 
tranzicione ekonomije suoćavaju se sa mnogim izazovima. Listazemalja nikada nije konačna. Sa druge strane, mali broj tranzicionih ekonomija je usvojio ovu strategiju monetarne politike. Takvi primeri u regionu jugoistočne Evrope jesu Srbija i Albanija. Ipak, ne postoji uniforman obrazac, stoga, zemlje moraju učiti na osnovu sopstvenih iskustava i iskustava drugih zemalja koje su prošle celokupan proces.

Ovaj rad se bavi prikazom inflatornog targetiranja kao strategije monetarne politike, neophodnim uslovima za uspešnu implementaciju, prednostima $i$ nedostacima, kao $i$ ishodima $i$ izazovima sa kojima se suoćavaju tržišne ekonomije u nastajanju $i$ tranzicione ekonomije $u$ toku procesa definisanja, kao i tokom procesa same implementacije ove strategije monetarne politike.

Ključne reči: inflatorno targetiranje / monetarna politika / stabilnost cena / centralna banka / finansijska stabilnost

\section{BIBLIOGRAPHY}

1. Amato, J., Gerlach, S., (2001). Inflation Targeting in Emerging Market and Transition Economies: Lessons after a decade, European Economic Review, 46, 781-790.

2. Bernake, B., Mishkin, F. S. (1997). Inflation Targeting: A New Framework for Monetary Policy?, NBER Working Paper No. 5893. Retrieved from http://www2.gsb.columbia.edu/faculty/fmishkin/PDFpapers/w5893. pdf

3. Cabral, R. (2006). Does Inflation Targeting Matter for Emerging Market Economies?, EGAP Working Paper No. 2006-1.

4. Cukierman, A. (1996). The Economics of Central Banking, in: H. Wolf (ed.) Contemporary Economic Issues: Macroeconomic and Finance (IEA Series), Basingstoke, UK: Macmillan.

5. Fabris, N. (2006). Inflation Targeting with Special Review on Application in Serbia, Panoeconomicus, 4, 389-405.

6. Freedman, C., Otker-Robe, I. (2009). Country Experiences with the Introduction and Implementation of Inflation Targeting, IMF Working Paper WP/09/161.

7. Freedman, C., Otker-Robe, I. (2010). Important Elements for Inflation Targeting for Emerging Economies, IMF Working Paper WP/10/113.

8. Gerlach, S. (1999). Who targets inflation explicitly?, European Economic Review, 43, 1257-1277. 
9. Johnson, D. (2002). The Effect of Inflation Targeting on the Behavior of Expected Inflation: Evidence from an 11 Country Panel, Journal of Monetary Economics, 49, 1521-1538.

10. Krause, S., Mendez, F. (2008). Institutions, arrangements and preferences for inflation stability: Evidence and lessons from a panel data analysis, Journal of Macroeconomics, 30, 282-307.

11. Lin, S., Ye, H. (2009). Does inflation targeting make a difference in developing countries?, Journal of Development Economies, 89, 118-123.

12. Mishkin, F. S., Schmidt-Hebbel, K. (2006). Does Inflation Targeting Make a Difference?, Central Bank of Chile Working Papers No. 404. Retrieved from http://www.bcentral.cl/estudios/documentos-trabajo/ pdf/dtbc404.pdf

13. Mishkin, F. S. (2000). Inflation Targeting in Emerging Market Economies, NBER Working Paper No. 7618. Retrieved from http://www.nber.org/ papers/w7618

14. Mishkin, F. S. (2009). The Economics of Money, Banking and Financial Markets, 9th edition, Perason: London.

15. Momirovic, D. M. (2008). Application of New Framework Monetary Policy-Corridor towards Full Implementation of Targeting of Inflation Strategies in Serbia, Finansije, Godina LXIII, Broj: 1-6/2008, 50-74.

16. Mukherjee, S., Bhattacharya, R. (2011). Inflation Targeting and Monetary Policy Transmission Mechanisms in Emerging Market Economies, IMF Working Paper WP/11/229.

17. Roger, S. (2009). Inflation Targeting at 20: Achevements and Challenges, IMF Working Paper 09/236, October, 2009.

18. Scott, R. (2009). Inflation Targeting at 20: Achievements and Challenges, IMF Working Paper WP/09/236.

19. Svensson, L. (1999). Inflation Targeting as a Monetary Policy Rule, Journal of Monetary Economics, 43, 607-654.

20. Woodford, M. (2012). Inflation Targeting and Financial Stability, NBER Working Paper No. 17967. Retrieved from http://www.nber.org/papers/ w17967. 